\title{
EFFECT OF IRRIGATION MANAGEMENT ON WHEAT PRODUCTION IN FARAFRA OASIS - EGYPT
}

\section{H. A. M. Hiekal ${ }^{1}$, M. A. El-Farrah ${ }^{2}$, W. A. El-Sherbiny ${ }^{3}$ and A. A. Abd El-Lateef ${ }^{4}$}

${ }^{1}$ Assoc. Prof., Soil, and Water Conservation Dept., Desert Res. Center, Cairo, Egypt.

${ }^{2}$ Res., Soil and Water Conservation Dept., Desert Res. Center, Cairo, Egypt.

${ }^{3}$. Assoc. Prof., Soil Chem. \& Phys. Dept., Desert Res. Center, Cairo, Egypt.

${ }^{4}$ Prof., Crop Prod. Dept., Desert Res. Center, Cairo, Egypt.

*E-mail: hmhekal@gmail.com

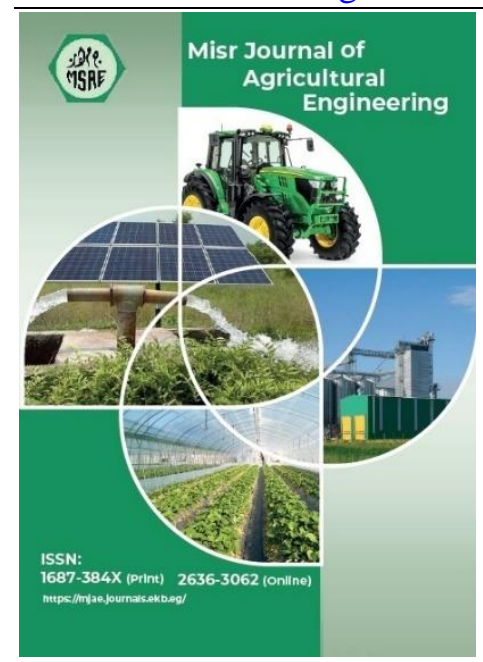

(C) Misr J. Ag. Eng. (MJAE)
Keywords:

Management practices, water distribution method, water use efficiency, water rationalization

\section{ABSTRACT}

Field experiments were conducted in villages named Subih (F1) and Al-Kifah (F2), Al-Farafra Oasis, New Valley Governorate, Egypt, during the winter season 2015-2016 by cultivating the wheat crop. Two management practices were carried out: Traditional management practices (TMP) under the conventional agriculture conducted by farmers' practices and improved management practices (IMP), which adopted long narrow borders irrigation system, LASER soil surface leveling for F1was 0.15 and $0.10 \%$ with $F 2$ as longitudinal slope, mature organic compost 0,30 and $50 \mathrm{~m}^{3} \mathrm{ha}^{-1}$, two water distribution technique as spill controlled pipes $(S P)$ and perforated controlled pipes $(P P)$, and two inflow rates produced by developed irrigation management guidance program (WinSRFR 5.1.1) which were under F1 conditions (q1) and (q2) in an average of 135 and 99 Lpm of border width, respectively, and it was 48 and $42 \mathrm{Lpm}$, respectively, under $F 2$. Results showed that management can be optimized then irrigation water rationalized by using simulation models. TMP in F1 and F2 conditions consumed 7635 and 6952 $\mathrm{m}^{3} \mathrm{ha}^{-1}$ on average, respectively, compared with IMP, by applying $q 1$ under F1 and F2, saving water from 12.0 to $13.6 \%$ and from10.0 to $11.5 \%$, respectively, upon compost rates and water distribution techniques. Grain yields increase by IMP 22.0 to 24,3 and 24.2 to $29.6 \%$ for $q 1$ of $F 1$ and $F 2$, respectively. Irrigation water use efficiency of grain yield (IWUEg) were 0.77 and 0.79 $\mathrm{kg} \mathrm{m}^{-3}$ in $\mathrm{F} 1 \mathrm{~T}$ and $\mathrm{F} 2 \mathrm{~T}$, respectively, the increment percentage reached 25.0 - 43.8 and 15.0 - 24.1\% for q1 and $q 2$ in IMP.

\section{INTRODUCTION}

$\mathrm{W}$ ith increasing demands, limited water resources, the need to minimize adverse environmental consequences of irrigation or chemical fertilizers the modern irrigation technology and compost applications will undoubtedly play an important role in the future of Egyptian agriculture, Abdelmageed et al., (2019). The efficiency of scheme irrigation is the product of field application efficiency and the conveyance efficiency of the distribution system as well as controlling the maximum and minimum amount of water that can 
be withdrawn from the groundwater source. Lecina et al., (2009) analyzed this effect and concluded that the on-farm irrigation efficiency improvement and the decrease of conveyance losses will result in a very important decrease in irrigation runoff and deep percolation losses. As a consequence of the reduction of deep percolation, the mass of exported fertilizers and other salts will decrease, and then it leads to better control of fertilizer application and decreasing fertilizer use. A certain minimum quantity of groundwater is to be withdrawn that to avoid water logging in the area and prevent excessive lowering of groundwater level, which be gained from weak management or poor design. The degradation of natural resources is part of an endemic cycle of poverty, lack of viable production alternatives, and uncoordinated regional development, (FAO, 2010), thus there is a great need for establishing improved management programs to overcome agro-environmental challenges. This is required a more supportive extension role to help farmers concerning develop appropriate farming systems, especially, irrigation systems. One of the important criteria in determining best management practices for irrigated agriculture is the realizing of the interaction between irrigation system performance and the movement of water and solutes through the soil sector. Over the past decade, there has been a gradual shift in Egypt towards development the of farm mechanization systems, efficient use of equipment required for cultivating basins, and borders in long strips, Clemmens et al., (1999). Hamza and Anderson (2005) reported that soil compaction is increased by low soil organic matter content and use of tillage or grazing at high soil moisture content. Soil compaction increases soil strength and decreases soil physical fertility through decreasing storage and supply of water and nutrients, which leads to additional fertilizer requirements, which means increasing the production cost. Knowledge of the exact amount of water required by different crops in a given set of climatic conditions of a region is a great help in planning the irrigation scheme, irrigation scheduling, and effective design or management of irrigation system when attempting to improve water-use efficiency in irrigated agriculture. Dorrenbos and Pruitt (1977) reported that the water requirements of crops vary substantially during the growing period due mainly to variations in crop canopy and climatic conditions. The absence of appropriate irrigation management and wrong water estimation for different crops in Egypt is probably the main reasons for increasing the irrigated agricultural water use, Ismail (2002). Bautista et al., (2009) concluded that optimized design and operation of surface irrigation systems translate into high levels of performance. With WinSRFR, the analyst can visualize the range of solutions that will result in near-optimal performance, and study the sensitivity of the recommended design or operational strategy. Bautista et al., (2012) reported that WinSRFR is a software package for the hydraulic analysis of surface irrigation systems.

AL-Frafra Oasis in New Valley Governorate represents $30.1 \%$ of the New Valley Governorate is suffering from many constraints. Thus, it is exposed to decreasing yield productivity compared with other Egypt regions that affect greatly growth, yield and its components of cereal plants. Wheat (Triticumaestivum L.) is the most important cereal crop, which is considered the main staple food for the Egyptian people. Egypt's total wheat production of grains in the 2014/2015 season reached about 9,460 million tons resulted from about 3.24 million feddan (FAO, 2013). Improving the productivity of this crop is the main task due to its short supply, which mandated importing about $50 \%$ of the needed wheat. Therefore, enhancing irrigation methods, proper irrigation scheduling, and addition leaching water requirements 
suited to the environmental conditions of Al-Frafra Oasis is vital to sustainable agriculture. Management must carry out taking into its account the improvement of irrigation systems, and the evolution of the soil-hydrogeological process of agrarian fields under the influence of irrigation and drainage, Morozov et al., (2010). Sharkawy et al., (2017) concluded that the development of irrigation systems in marginal areas is important because it helps in: 1) Save water for the cultivation of new land areas, 2) Avoid water scarcity in light of climate change, 3) Raising the efficiency of water use, and 4) Avoid raising groundwater table level.

\section{Objectives of this study were to:}

- Monitoring the effect of management in enhancing crop production, by applying the improved management practices (IMP): through developing surface on-farm irrigation scheme or method, and besides this, select a suited irrigation scheduling for wheat crop production in two sites of Subih and Al-Kifah villages in Farafra Oasis;

- Assessment of the water use efficiency of crop under two water inflow rates and with applying different rates of plant residues compost; and

- Rationalization groundwater used amounts, and also to avoid water table rising under study area conditions.

\section{MATERIALS AND METHODS}

The field experiments were conducted at Al-Farafra Oasis, New Valley Governorate, Egypt, during the growing winter season 2015 - 2016 by cultivated wheat crop in two sites: Subih Village (F1), and Al-Kifah Village (F2). The locations sites shown in Table (1), two management practices were carried out as follows: The first was traditional management practices (TMP) under the conventional agriculture and irrigation practices and the second was improved management practices (IMP) which included all recommended agricultural practices were done during land preparation included: leveling soil surface using LASER technique for longitudinal slope $0.15 \%$ for $\mathrm{F} 1$ and $0.10 \%$ for $\mathrm{F} 2$ according to each soil properties and addition of 0,30 and $50 \mathrm{~m}^{3} \mathrm{ha}^{-1}$ of mature compost plant residues (CPR) represented as $\mathrm{C} 0, \mathrm{C} 1$, and $\mathrm{C} 2$ sub-treatments, respectively. Long narrow borders irrigation system using two water distribution technique as spill controlled pipes (SP) and perforated controlled pipes (PP), the addition of salt leaching requirements, the addition of effective microorganism's solution (EM) at the rate of $50 \mathrm{~L} \mathrm{ha}^{-1}$, seeds of winter wheat cultivar Misr 2 at the rate of $120 \mathrm{~kg} \mathrm{ha}^{-1}$.

The developed irrigation management guidance program (WinSRFR 5.1.1) was used to determinate slope and flow rate which were (q1) and (q2) in average 135 and 99 Lpm each meter of border width, respectively, under F1 conditions, and were 48 and $42 \mathrm{Lpm}$, respectively, under F2. Pretreatment was conducted in one case (F1 and q1) to check the compatibility of the program (WinSRFR 5.1.1) with the real case of studied farms. The data of advance and recession time showed good relation $(88.57 \%)$ with the grogram outputs, for example, the real advance time was $2.3 \mathrm{~h}$, while the program advance time output was $2.6 \mathrm{~h}$.

The area of each experiment of IMP $5760 \mathrm{~m}^{2}$ (0.576 ha) divided into four equal areas of 1440 $\mathrm{m}^{2}$, each one allocated for inflow rate: (q1) or (q2) treatment, applied through water distribution method: SP or PP in four replicates (4x90m), q1 and q2 were in F1 conditions with an average of 135 and $99 \mathrm{Lpm}$ each meter of border width, respectively, while it was in F2 conditions with an average of 48 and $42 \mathrm{Lpm}$ each meter of border width, respectively. Each replicates divided 
into three compost additions sub-treatments as $\mathrm{C} 0, \mathrm{C} 1$, and $\mathrm{C} 2$ by randomized (30 m length of each border).

Area of $900 \mathrm{~m}^{2}$ represented TMP as control treatment (T) in each farm by short borders in four replicates $(4 \times 22.5 \mathrm{~m})$. The farmer prepared and managed his farm as usual included the addition of farmyard manure (FYM) at a rate of $30 \mathrm{~m}^{3} \mathrm{ha}^{-1}$ during soil preparation of short borders as traditional irrigation method $10 \times 12.5 \mathrm{~m}$ and longitudinal slope $0.04 \%$. Average measured inflow rates of TMP were 157and $142 \mathrm{Lpm}$ for each meter of border width in F1 and F2, respectively. The seeds (Misr2) rate using was150 kg ha-1. Table (2) showed the analysis of some chemical properties of the applied (FYM) and compost of plant residues (CPR).

Table (1): Location of experiments in each farm

\begin{tabular}{|c|c|c|c|}
\hline Village name & $\begin{array}{c}\text { Site will } \\
\text { denote as }\end{array}$ & Latitude (N) & Longitude (E) \\
\hline Subih & F1 & $27^{\circ} 4^{\prime} 13.872^{\prime \prime}$ & $27^{\circ} 53^{\prime} 4.056^{\prime \prime}$ \\
\hline Al-Kefah & F2 & $26^{\circ} 50^{\prime} 57.48^{\prime \prime}$ & $27^{\circ} 54^{\prime} 5.7132^{\prime \prime}$ \\
\hline
\end{tabular}

Table (2): Some chemical properties of the applied FYM and CPR

\begin{tabular}{|c|c|c|c|c|c|c|c|c|c|c|c|}
\hline $\begin{array}{c}\text { Type } \\
\text { applied }\end{array}$ & OM & $\mathrm{pH}$ & $\mathrm{EC}$ & Total C & $\begin{array}{c}\text { Total } \\
\mathrm{N}\end{array}$ & $\begin{array}{c}\mathrm{C} / \mathrm{N} \\
\text { ratio } \\
(\%)\end{array}$ & $\begin{array}{c}\text { Total } \\
\mathrm{P} \\
(\%)\end{array}$ & $\begin{array}{c}\text { Total } \\
\mathrm{K} \\
(\%)\end{array}$ & $\begin{array}{c}\text { Total Fe } \\
\left(\mathrm{g} \mathrm{kg}^{-1}\right)\end{array}$ & $\begin{array}{c}\text { Total } \\
\mathrm{Mn}\end{array}$ & $\begin{array}{c}\text { Total } \\
\left(\mathrm{g} \mathrm{kg}^{-1}\right)\end{array}$ \\
\hline $\mathrm{Zn} \mathrm{kg}$ & 30.06 & 7.11 & 1.66 & 23.77 & 1.75 & 13.61 & 0.47 & 1.12 & 2246.0 & 744.0 & 144.0 \\
\hline FYM & 42.24 & 6.96 & 1.42 & 20.03 & 1.91 & 10.49 & 0.36 & 0.91 & 2066.0 & 701.0 & 115.0 \\
\hline
\end{tabular}

Concerning the IMP and developed distribution irrigation water system, the first one was water spill controlled pipes (SP)as equal parts of PVC that have $1.0 \mathrm{~m}$ length $(63 \mathrm{~mm}$ diameter) installed in irrigation channel along the upper end, which pass the water according to the equal inflow rates by controlled water head level above spills, inlet orifices that can be open or close by easily removed PVC caps to control of water applied, according to the technique of Hiekal (2007), to realize adequately inflow rate each farm conditions as q1 and q2. While the second one was perforated controlled pipes (PP) as fabricated from PVC with a diameter of $160 \mathrm{~mm}$ used to pass the irrigation water from the excavated channel through water inlets that can be open or close (by easily released PVC caps to control water applied by gravity) to discharge the water from $50 \mathrm{~mm}$ diameter orifices at the side of outflow pipe each $72 \mathrm{~cm}$ along the border width (5 orifices each replicate) the inflow rates $\mathrm{q} 1$ and $\mathrm{q} 2$ were applied under each farm conditions. Inflow rates were measured and adjusted by use of a volumetric container and stopwatch, which predetermined according to the technique of Merriam et al., (1983). Irrigation cutoff was at 85 $\%$ of plot length and runoff was negligible, which the plots were closed-ends.

Under considered IMP treatments, irrigation water applied was calculated according to the following equation:IWA $=((\boldsymbol{A} * \boldsymbol{E T} \boldsymbol{c} * \boldsymbol{I} \boldsymbol{i}) /(\boldsymbol{E} \boldsymbol{a} * \mathbf{1 0 0}))+\boldsymbol{L R}$, where: IWA = Irrigation water applied $\left(\mathrm{m}^{3}\right), \mathrm{A}=$ Plot area $\left(\mathrm{m}^{2}\right), \mathrm{ET}_{\mathrm{c}}=\mathrm{Crop}$ water requirements $\left(\mathrm{mm} \mathrm{day}{ }^{-1}\right)$, Ii $=$ Irrigation intervals (day), $\mathrm{Ea}=$ Application efficiency $(\%)$, and $\mathrm{LR}=$ Leaching requirements $\left(\mathrm{m}^{3}\right)$. Under field conditions and water qualities, LR was added as $12 \%$ of water requirements. 
The amount applied during each irrigation event was appropriate to the crop's growth stage according to the methodology as described by Dorrenbos and Pruitt (1977). Soil water content was measured by gravimetric method (Merriam et al., 1983) before and after irrigation events in each water distribution technique to a depth of $1 \mathrm{~m}$ with $0.2 \mathrm{~m}$ increments to evaluate the soil moisture distribution and irrigation performance. Application efficiency (Ea) was calculated for the $100 \mathrm{~cm}$ soil depth according to James (1988) as average values of $1^{\text {st }}, 3^{\text {rd }}$ and $5^{\text {th }}$ irrigation events as follow: $\mathbf{E a} \%=\left(\left(\mathbf{W}_{\mathrm{s}} / \mathbf{W}_{\mathbf{f}}\right) * \mathbf{1 0 0}\right)$, where: Ea\% = water application efficiency, $(\%), \mathrm{W}_{\mathrm{s}}=$ amount of water stored in the root zone, $\left(\mathrm{m}^{3}\right)$, and $\mathrm{W}_{\mathrm{f}}=$ amount of water added to each plot, $\left(\mathrm{m}^{3}\right)$. However, the distribution uniformity (DU) was calculated according to ASCE (1978) as follows: $\mathrm{DU}=$ (average low quarter depth of water infiltrated / average depth of water infiltrated). Irrigation water use efficiency (IWUE) was measured according to James (1988) as follows: $\boldsymbol{I} \boldsymbol{W} \boldsymbol{E}=\boldsymbol{Y} / \boldsymbol{W a}$, where: IWUE= irrigation water use efficiency, $\left(\mathrm{kg} \mathrm{m}^{-3}\right), \mathrm{Y}=$ total grain or biological yield, $\left(\mathrm{kg} \mathrm{ha}^{-1}\right)$, and $\mathrm{W}_{\mathrm{a}}=$ total applied water, $\left(\mathrm{m}^{3} \mathrm{ha}^{-1}\right)$.

Table (3): Some initial soil and water properties for the studied sites

\begin{tabular}{|c|c|c|c|}
\hline Item & $\begin{array}{l}\text { Depth } \\
(\mathbf{c m})\end{array}$ & Subih (F1) & Al-Kifah(F2) \\
\hline Soil texture class & $0-60$ & Clay & sandy loam \\
\hline Bulk density $\left(\mathrm{g} \mathrm{cm}^{-3}\right)$ & $0-60$ & 1.34 & 1.54 \\
\hline Saturated hydraulic conductivity $\left(\mathrm{cm} \mathrm{h}^{-1}\right)$ & $0-60$ & 2.4 & 0.7 \\
\hline Field capacity (V\%) & $0-60$ & 36 & 15.3 \\
\hline Wilting point $(\mathrm{V} \%)$ & $0-60$ & 13.7 & 7.0 \\
\hline Available water $(\mathrm{V} \%)$ & $0-60$ & 22.3 & 8.3 \\
\hline \multirow{2}{*}{ Range and avg. values of $\mathrm{pH}$} & $0-30$ & $(7.03-8.37) 7.68$ & $(6.76-8.24) 7.62$ \\
\hline & $30-60$ & $(6.56-8.74) 7.87$ & (7.17-8.09) 7.64 \\
\hline \multirow{2}{*}{ Range and avg. values of EC $\left(\mathrm{dS} \mathrm{m}^{-1}\right)$} & $0-30$ & $(5.41-7.11) 6.29$ & $(6.02-7.28) 6.65$ \\
\hline & $30-60$ & $(5.45-7.13) 6.55$ & $(5.93-7.20) 6.60$ \\
\hline \multirow{2}{*}{ Range and avg. values of organic matter (\%) } & $0-30$ & $(0.41-0.54) 0.48$ & $(0.36-0.52) 0.43$ \\
\hline & $30-60$ & $(0.32-0.50) 0.42$ & $(0.40-0.49) 0.44$ \\
\hline \multirow{2}{*}{ Range and avg. values of total nitrogen $(\%)$} & $0-30$ & $(0.49-0.60) 0.55$ & $(0.62-0.81) 0.71$ \\
\hline & $30-60$ & $(0.56-0.79) 0.67$ & $(0.58-0.84) 0.69$ \\
\hline \multirow{2}{*}{$\begin{array}{l}\text { Range and avg. values of available } \\
\text { phosphorus (ppm) }\end{array}$} & $0-30$ & 19.93 (17.21 - 22.06) & $(14.95-22.6) 19.31$ \\
\hline & $30-60$ & 19.88 & 20.19 \\
\hline \multirow{2}{*}{$\begin{array}{l}\text { Range and avg. values of exchangeable } \\
\left.\text { potassium (meq } 100 \mathrm{~g} \mathrm{soil}^{-1}\right)\end{array}$} & $0-30$ & $(1.73-2.27) 2.06$ & $(1.52-1.92) 1.77$ \\
\hline & $30-60$ & $(1.69-2.35) 1.94$ & $(1.28-1.94) 1.73$ \\
\hline \multicolumn{2}{|l|}{$\begin{array}{l}\text { Range and avg. values of drainage water salinity } \\
\left(\mathrm{dS} \mathrm{m}^{-1}\right)\end{array}$} & $(4.04-6.01) 4.96$ & $(4.48-6.08) 5.42$ \\
\hline \multicolumn{2}{|l|}{ Range and avg. values of water table depth $(\mathrm{cm})$} & $(77-80) 78.75$ & $(90-115) 103.5$ \\
\hline
\end{tabular}

Representative soil samples were collected from experimental sites in depth from 0 to $30 \mathrm{~cm}$ and from 30 to $60 \mathrm{~cm}$ for the determination of some soil physical properties according to the methods described by Klute (1986) and some soil chemical properties according to the methods described by Black (1983). Table (3) shows some soil properties, and Table (4) shows some 
chemical properties of the irrigation water in the studied sites. Yield samples of wheat were taken along the field length (at $1^{\text {st }}, 2^{\text {nd }}, 3^{\text {rd, }}$ and $4^{\text {th }}$ quarters) with four replications, each replicate was one square meter harvested manually. All data of this study were statistically analyzed according to the technique of variance (ANOVA) for the factorial Randomized Complete Block Design. The Least Significant Difference (LSD) method was used to test the differences between treatment means at the $5 \%$ level of probability as described by Snedecor and Cochran (1990) and Fredriksen (1983).

Table (4): some chemical properties of the irrigation water in the studied sites

\begin{tabular}{|c|c|c|c|c|c|c|c|c|c|c|}
\hline \multirow[t]{2}{*}{ Site } & \multirow[t]{2}{*}{$\mathbf{P H}$} & \multirow{2}{*}{$\begin{array}{c}\mathrm{EC} \\
\left(\mathrm{dS} \mathbf{~ m}^{-1}\right)\end{array}$} & \multirow{2}{*}{$\begin{array}{c}\text { TDS } \\
\left(\mathrm{mg} \mathrm{L}^{-1}\right) \\
\end{array}$} & \multicolumn{4}{|c|}{ Soluble Cations $\left(\mathrm{meq} \mathrm{L}^{-1}\right)$} & \multicolumn{3}{|c|}{ Soluble Anions $\left(\operatorname{meq} \mathrm{L}^{-1}\right)$} \\
\hline & & & & $\mathbf{C a}^{++}$ & $\mathbf{M g}^{++}$ & $\mathbf{N a}^{+}$ & $\mathbf{K}^{+}$ & $\mathrm{HCO}_{3}^{-}$ & $\mathrm{Cl}^{-}$ & $\mathrm{SO}_{4}=$ \\
\hline $\mathrm{F} 1$ & 7.01 & 0.548 & 353.18 & 1.48 & 1.53 & 2.50 & 0.04 & 1.57 & 3.02 & 0.95 \\
\hline $\mathrm{F} 2$ & 7.14 & 0.639 & 420.30 & 1.68 & 1.46 & 3.22 & 0.05 & 2.02 & 3.24 & 1.14 \\
\hline
\end{tabular}

\section{RESULTS AND DISCUSSIONS}

\section{Realizing the WinSRFR simulation model:}

The optimized variables are used to describe irrigation scenarios to achieve the desired level of performance. These variables (particularly field slope and length) are difficult or expensive to modify. Once the system is operational Time to inflow cut-off, inflow rate, and the desired depth of application are management decisions that can be optimized using the simulation model to predict water advance, recession, and intake for sloped soil irrigated under farms conditions using optimal water management, which it can be obtained with a proper balance between the input variables. The results of the graphical outputs of WinSRFR simulation as a hydraulic summary, inflow hydrograph, advance, recession, and post-irrigation infiltration distribution for all treatments are studied.

\section{Results of a simulation model:}

The optimized variables are used to describe irrigation scenarios to achieve the desired level of performance. These variables (particularly field slope and length) are difficult or expensive to vary once the system is operational, which can be obtained with a proper balance between the input variables. Figs. (1 A-D) showed a given irrigation system, which takes into account were the downstream boundary condition and field slope, length and inflow rate of studied treatments. Therefore, the results of graphical outputs of WinSRFR simulation as hydraulic summary shows inflow hydrograph, advance, recession, time of irrigation, and post-irrigation infiltration distribution for all treatments.

\section{Irrigation application efficiency (Ea\%):}

At farm F1, the average values of Ea\% under traditional irrigation F1T and soil conditions (Fig. 2 - A), it is clear that about $81.8 \%$ of the water applied was useful or valuable for the crop depending on added FYM rate, but among the other treatments of IPM using SP method, it was significant differences compared with TMP which these average values of Ea \% were ranged from 90.9 to $92.7 \%$ by q1 and it was non-significant differences by q2 which ranged from 83.5 to $84.6 \%$. 


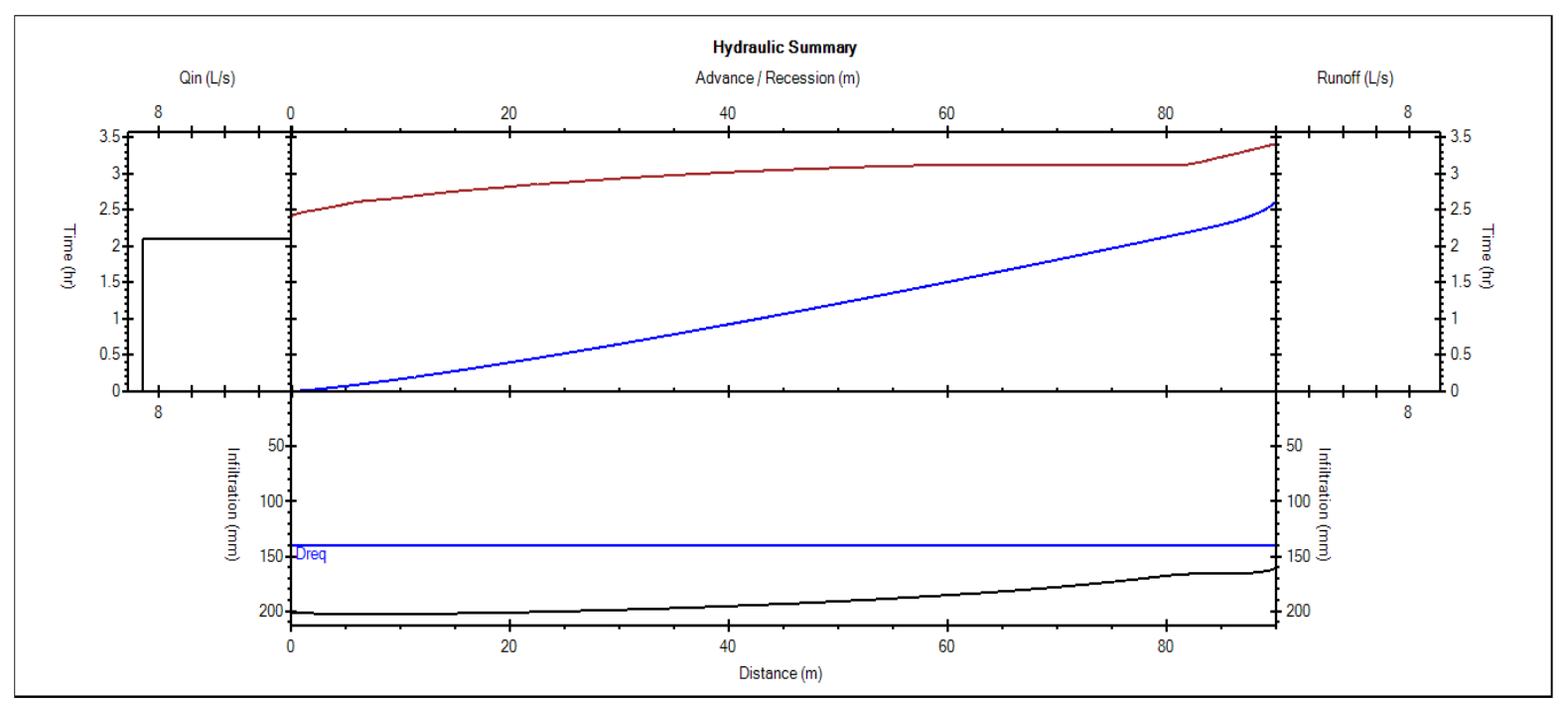

Fig. (1-A): Hydraulic summary of treatment F1q1:

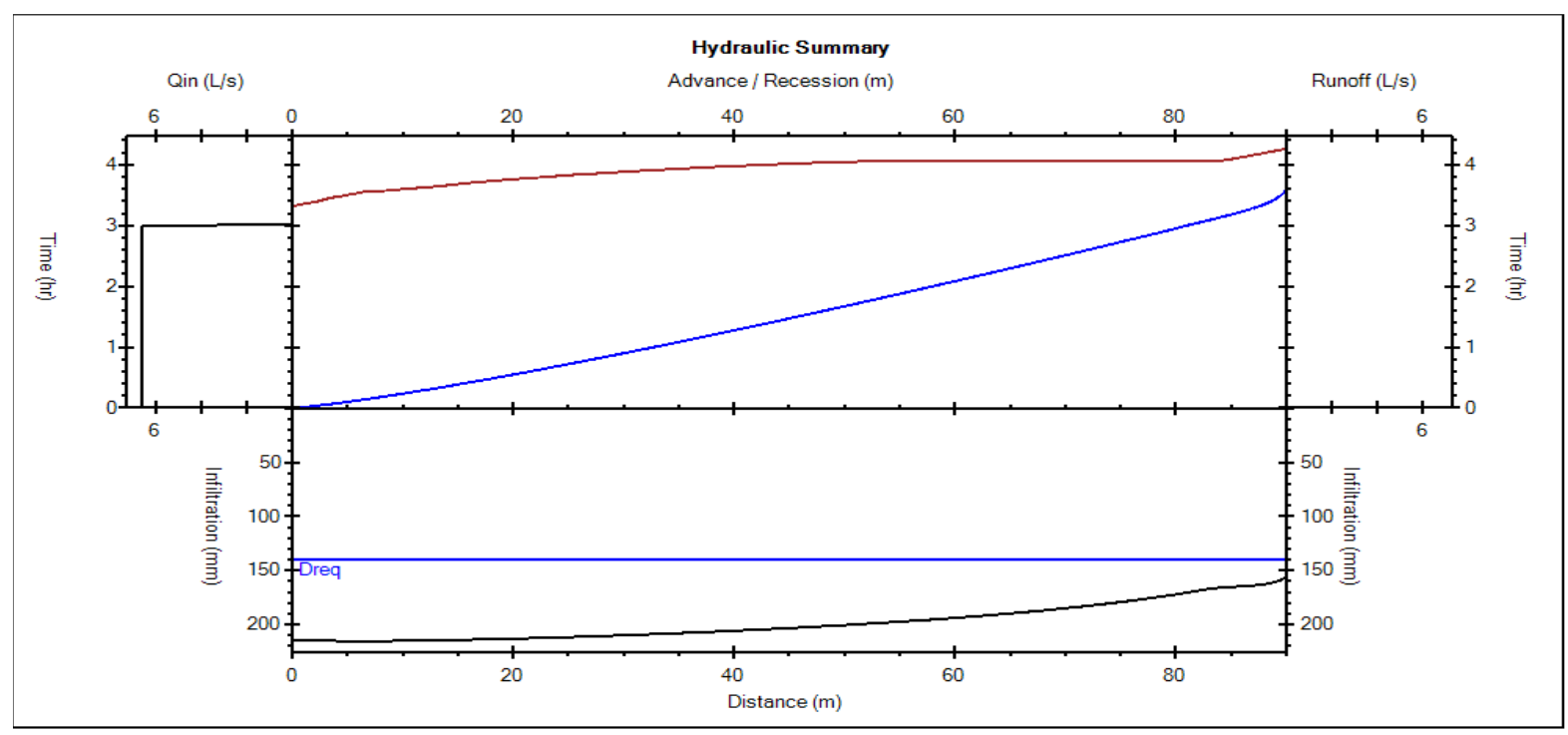

Fig. (1-B): Hydraulic summary of treatment F1q2

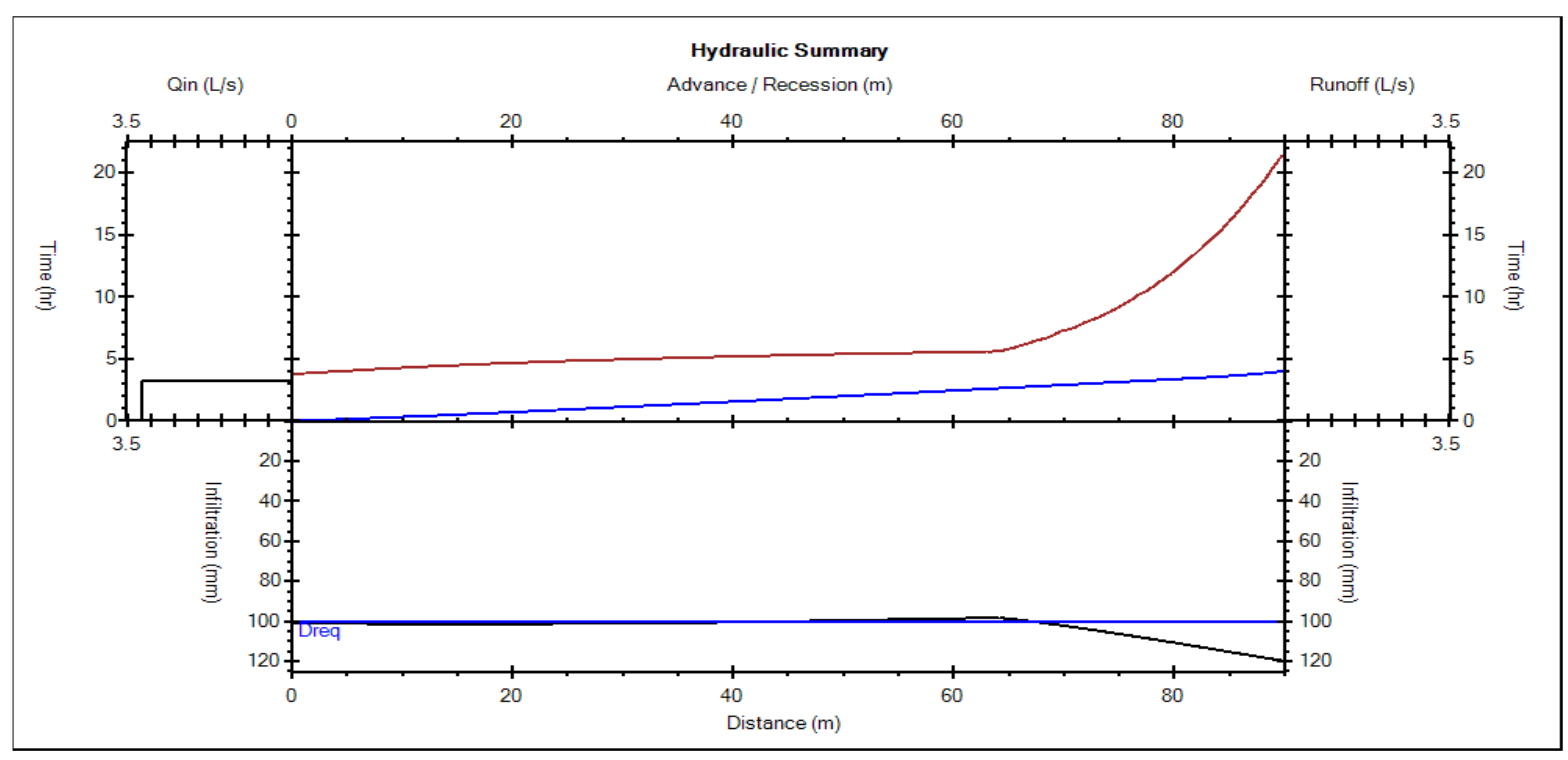

Fig. (1-C): Hydraulic summary of treatment F2q1 


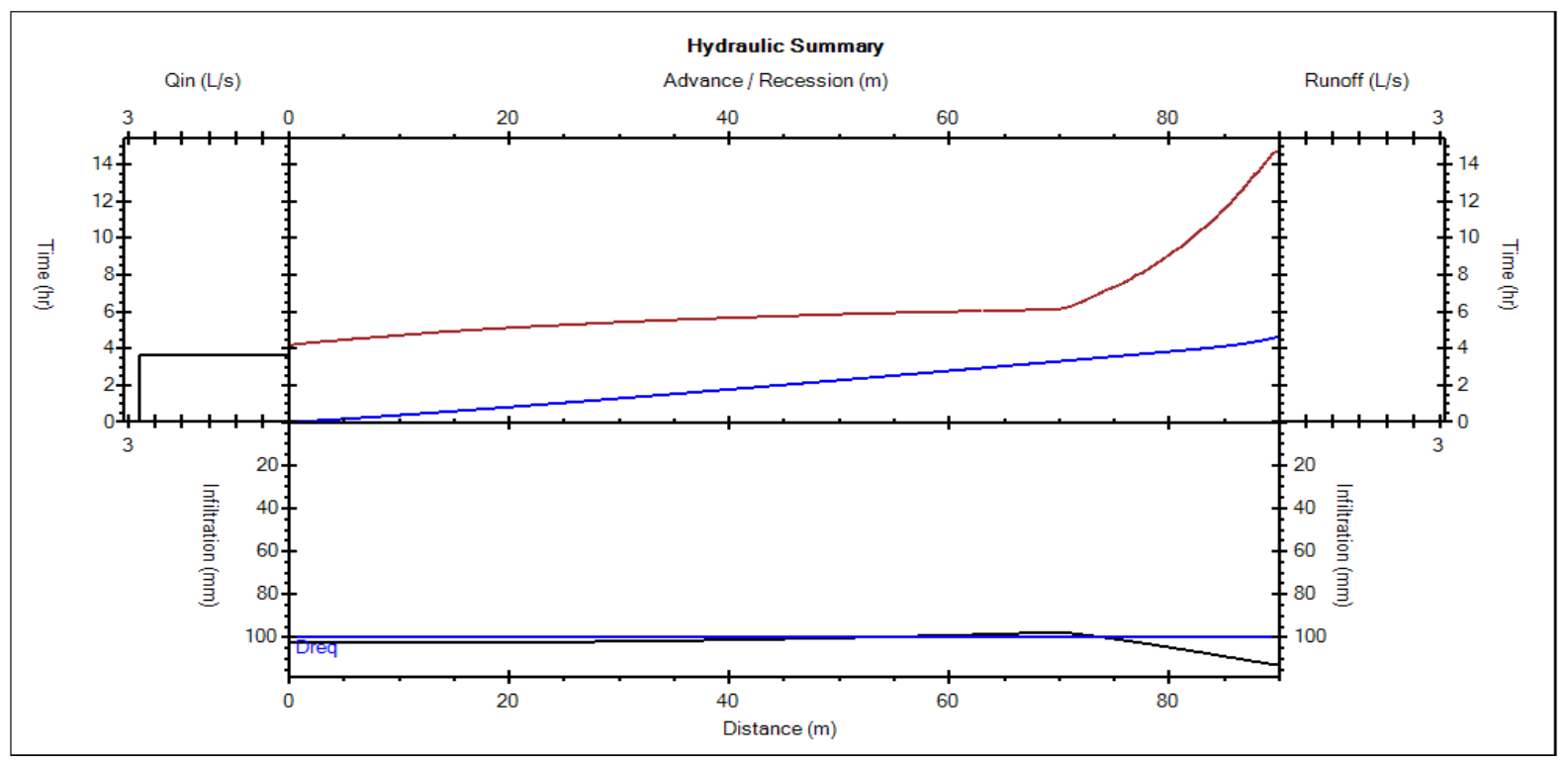

Fig. (1-D): Hydraulic summary of treatment F2q2

While, using the PP method (Fig. 2 - B), the same trend resulted with q1 and q2, in which the average values were ranged from 91.3 to $92.5 \%$, by q1 and ranged from 82.4 to $82.7 \%$ by q2. These results insuring that the q1 flow rate of IMP was suitable more than q2 under soil conditions of F1.

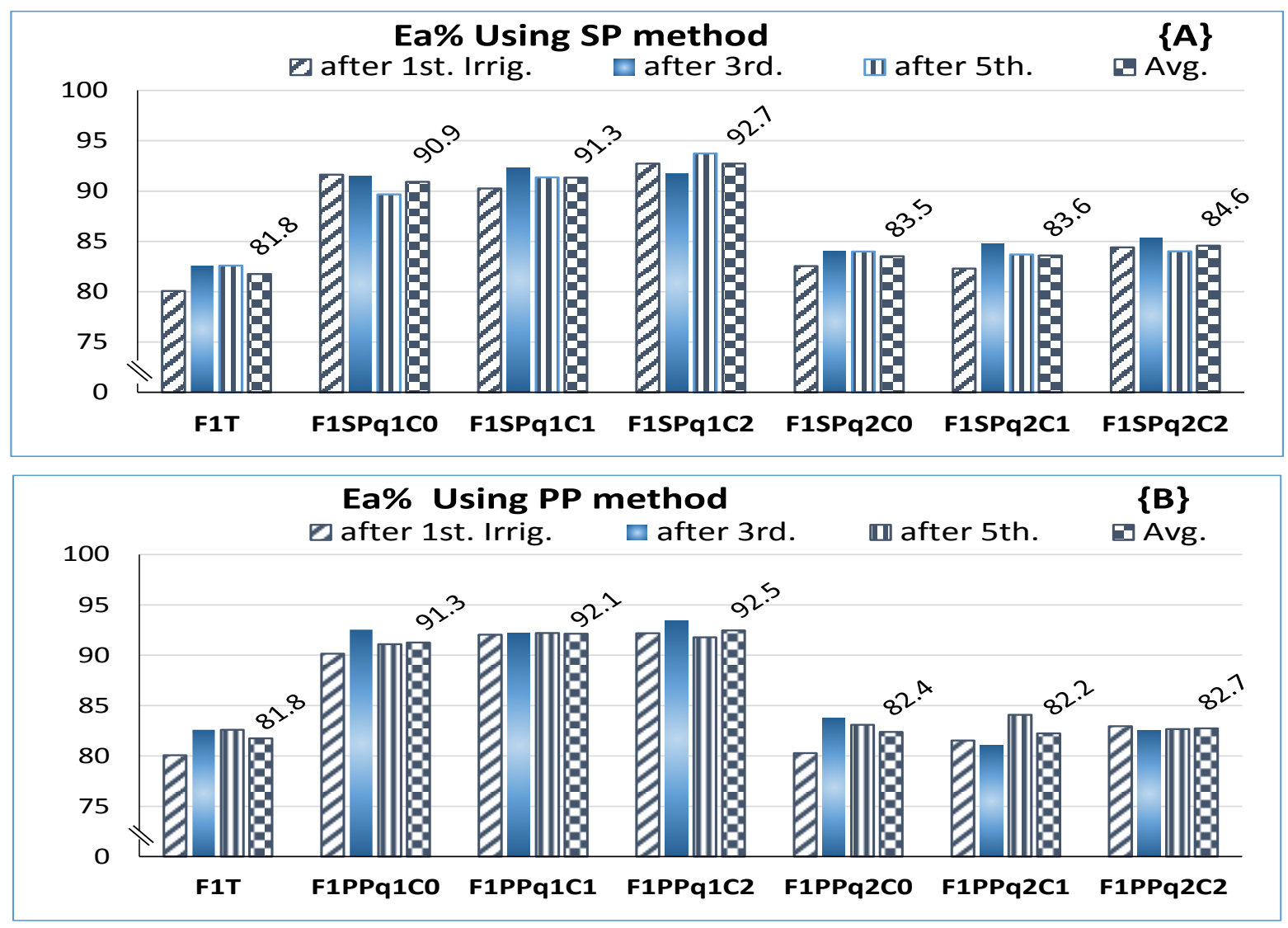

Fig. (2): Average application efficiency values (Ea \%) at F1 after $1^{\text {st }}, 3^{\text {rd. }}$ and $5^{\text {th. }}$ irrigation events for the irrigated wheat crop by TMP and IMP under different treatments of spill pipes SP $\{\mathbf{A}\}$ and perforated pipes $\mathrm{PP}\{\mathbf{B}\}$. 
While in farm 2, the average values of Ea \% under traditional irrigation F2T and soil conditions (Fig. 3 - A), it is clear that about $83.0 \%$ of the water applied was useful or valuable for the crop, but among the other treatments it was a significant difference compared with IMP and using SP method, these average values were ranged from 91.7 to $92.7 \%$ by q1 and ranged from 91.8 to $92.8 \%$ by q2, it was a non-significant difference between q1 and q2 with IMP. While under PP method (Fig. 3 - B), the average values were ranged from 93.0 to $93.5 \%$ with q1 and ranged from 91.9 to $92.9 \%$ by q2. Also, it was non-significant difference between q1 and q2 with IMP. Generally, in the treatments with high compost rates, the Ea \% average values were more than they in others under each farm conditions, as also indicated by Hodgkinsona et al., (2017) and Kanber et al., (2001).
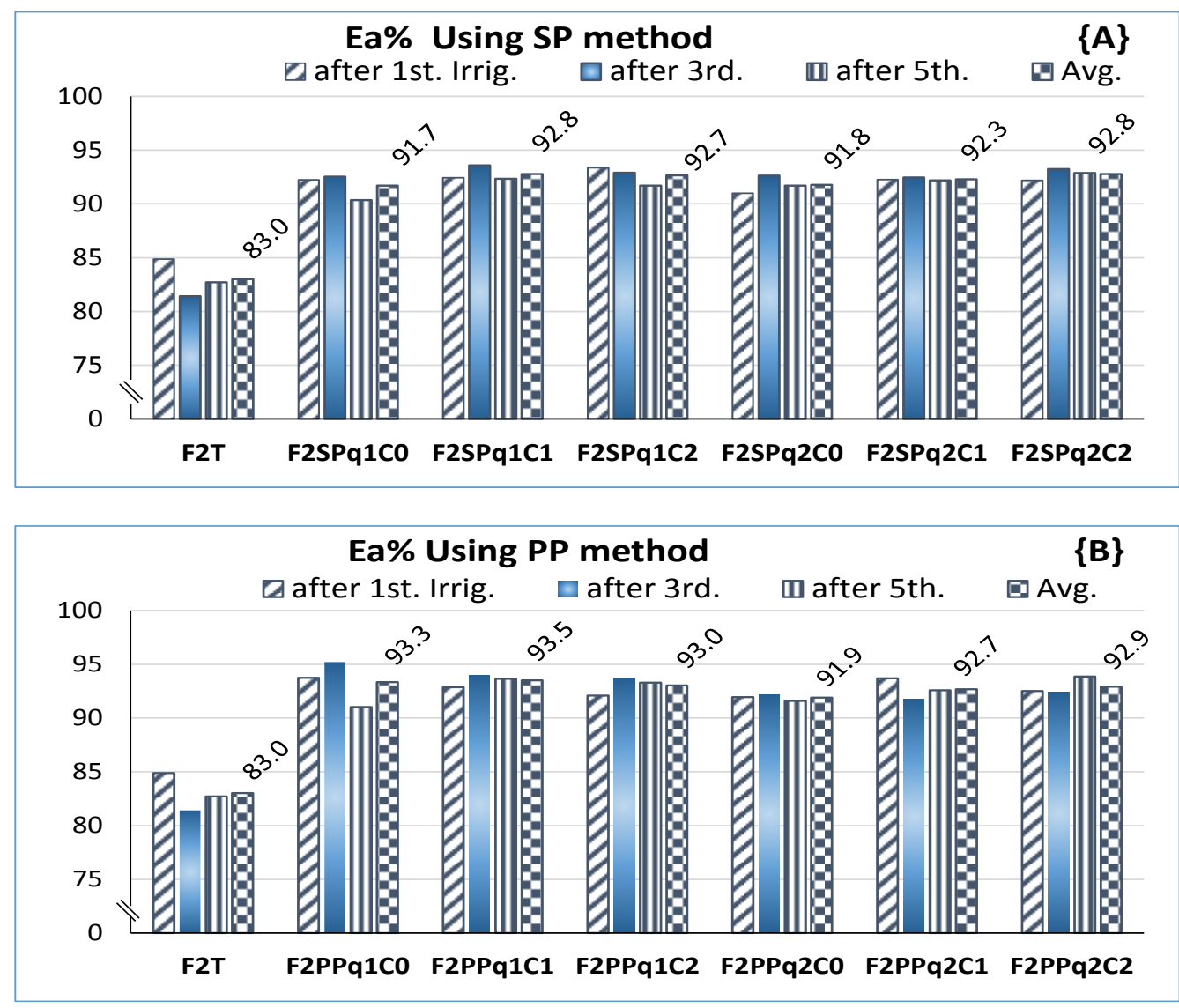

Fig. (3): Average application efficiency values (Ea \%) at F2 after $1^{\text {st }}, 3^{\text {rd. }}$ and $5^{\text {th. }}$ irrigation events for the irrigated wheat crop by TMP and IMP under different treatments of spill pipes SP $\{\mathbf{A}\}$ and perforated pipes $\mathrm{PP}\{\mathbf{B}\}$.

Note, to carry out suited management the amount of irrigation water required to crop growth must be considered besides irrigation efficiency value. Where the efficiency does not put the value of water requirement in its consideration. Thus, it is entirely possible to irrigate with Ea of $100 \%$ and still fail to grow or gain a decent crop

It is difficult to apply small irrigation depths by surface irrigation, difficult because the time of cutoff is often larger than the advance to provide for sufficient intake opportunity time along the field, Pereira (1999). However, Ea is considered as the index of most revealing performance due to the high potential for water losses through deep percolation. Many soil and 
crop combinations require a certain volume of applied water to be drained from the bottom of the soil profile to prevent salt accumulation. This additional infiltration requirement termed the leaching fraction is determined by the salinity of the applied water, the salinity of the soil solution and the crop salt tolerance. Optimizing solely based on Ea will lead to a general reduction in deep percolation volumes which may decline below the leaching requirement. Where leaching is important, it will impose an upper limit on Ea, Gillies (2008).

Stored water in the root zone is directly affected by the irrigation application efficiency (Ea \%). Fig. (4) Shows the values of applied water and the amount of stored water. The treatments, which have the highest efficiency $(\mathrm{Ea} \%)$ values have also the highest stored water proportional to the added irrigation water and vice versa.

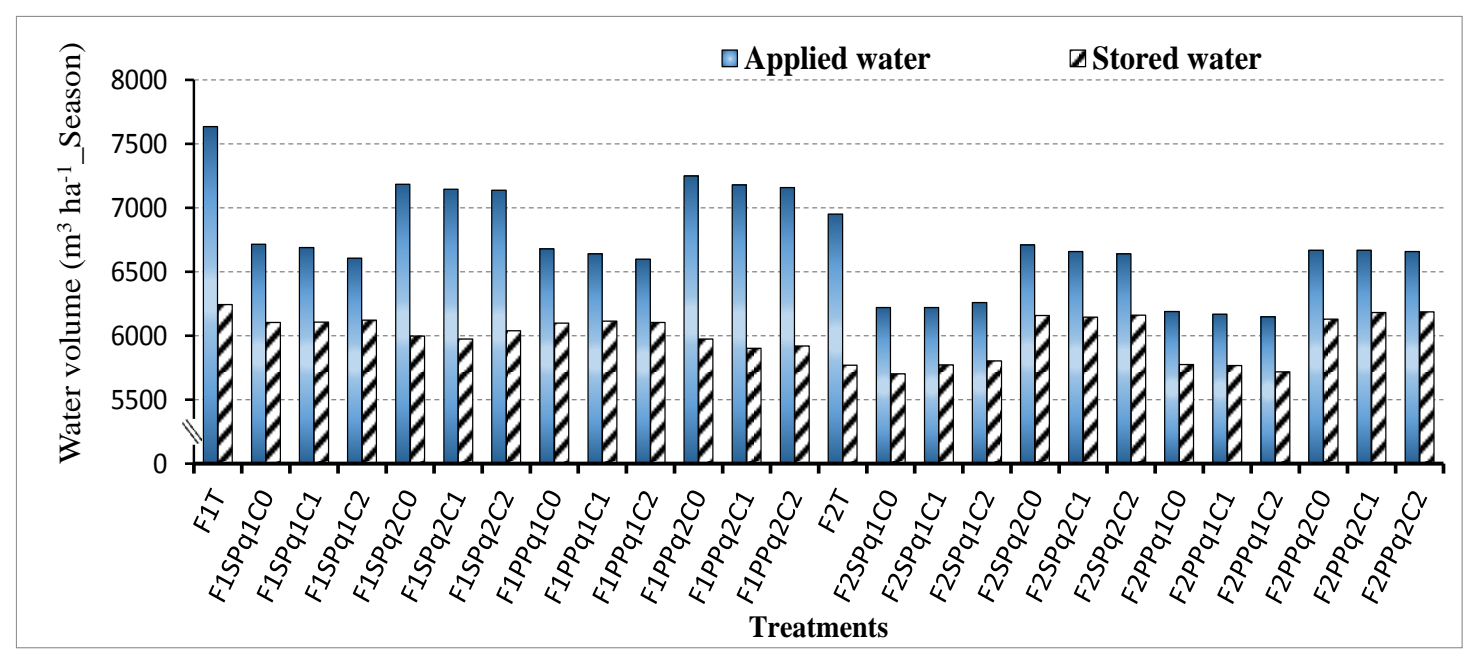

Fig. (4): Applied and store irrigation water in different treatments.

\section{Low-quarter Distribution Uniformity $\left(D U_{l q}\right)$ :}

At farm F1 from Fig. (5 - A), it is clear that at F1 using IMP and SP method the highest average value of DU $\mathrm{U}_{1}$ obtained with F1SPq1C2 treatment., it was 0.91 with an increment percentage of $53.4 \%$ compared with F1T, the increment percentages were ranged from 15.2 to $19.8 \%$ for the SPq2 treatments. While under F1PPq1C2 treatment the obtained average value was 0.89 with an increment percentage of $50.4 \%$ compared with $\mathrm{F} 1 \mathrm{~T}$. While, the increments were ranged from 13.2 to $23.1 \%$ with the PPq2 treatments as Fig. (5 - B). On the other farm F2 Fig. ( 6 A), it is clear that using IMP and SP method gave the highest average value of DU 1 , which was obtained with $\mathrm{F} 2 \mathrm{PPq} 2 \mathrm{C} 1$ treatment., it was 0.91 with an increment percentage of $41.2 \%$ compared with F2T. The increment percentages were ranged from 24.3 to $28.1 \%$ for the PPq1 treatments. While, under $\mathrm{F} 2 \mathrm{SPq} 2 \mathrm{C} 2$ treatment obtained average value was 0.9 with increment percentage of $38.4 \%$ compared with F2T. The increments were ranged from 27.6 to $29.4 \%$ with the SPq1 treatments as Fig. (6 - B).

Wheat yield and irrigation water use efficiency (IWUE):

- Average grain and biological wheat yield:

Regarding the effect of irrigation method, flow rate, and compost rates, it was clear that Fig. (7-A) shows the average values of grain and biological yield at farm 1 (F1). The grain yield of control treatment F1T recorded $5867 \mathrm{~kg} \mathrm{ha}^{-1}$ with significant differences compared with F1SPq1C1, F1SPq1C2, F1SPq2C1 and F1SPq2C2 treatments and the increment percentage values through SP treatments were 15.1, 22.0, 13.6 and 16.0\%, respectively. 

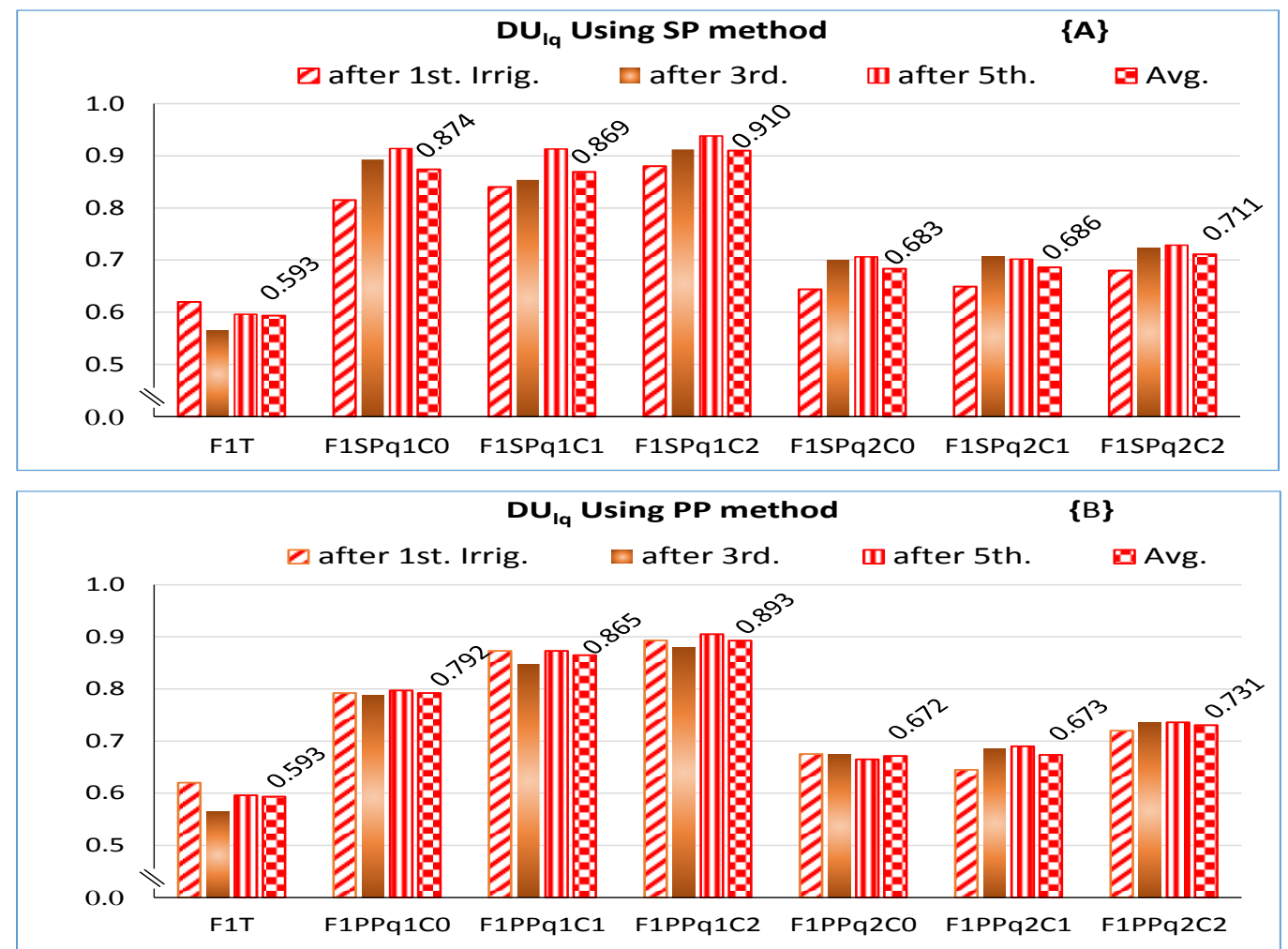

Fig. (5): Avg. low-quarter distribution uniformity values (DU $\left.U_{\mathrm{lq}}\right)$ at $\mathrm{F} 1$ after $1^{\text {st. }}, 3^{\text {rd. }}$ and $5^{\text {th }}$.irrigation events for the irrigated wheat crop by TMP and IMP under different treatments of spill pipes SP $\{\mathbf{A}\}$ and perforated pipes $\operatorname{PP}\{\mathbf{B}\}$.
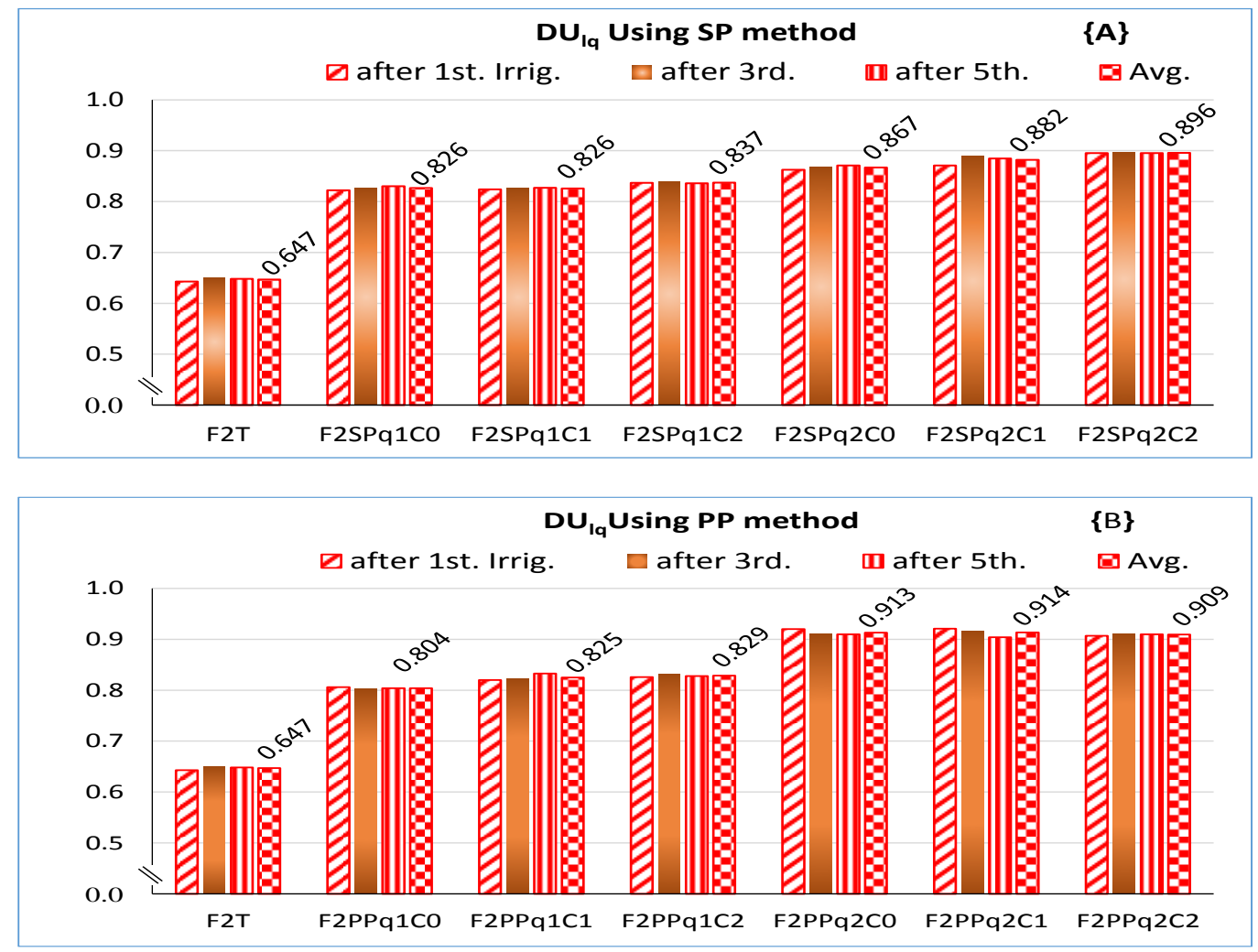

Fig. (6): Avg. low-quarter distribution uniformity values $\left(D U_{\mathrm{lq}}\right)$ at $\mathrm{F} 2$ after $1^{\text {st. }}, 3^{\text {rd. }}$ and $5^{\text {th }}$ irrigation events for the irrigated wheat crop by TMP and IMP under different treatments of spill pipes SP $\{\mathbf{A}\}$ and perforated pipes $\operatorname{PP}\{\mathbf{B}\}$. 
While the increment percentage values through applied PP treatments compared with F1T treatment which inducing significant increases reached from 14.5 to $24.3 \%$ by q1 and from 12.0 to $15.8 \%$ with increasing compost rates. Other applied treatments were a non-significant difference compared with F1T.

The average biological yield in F1T treatment recorded $15940 \mathrm{~kg} \mathrm{ha}^{-1}$, which was a significant difference compared to F1SPq1C2 treatment, which recorded an increase in biological yield reached $11.7 \%$, and other applied treatments were the non-significant difference. While the increment percentage values through applied PP treatments compared with F1T treatment reached 13.0, 15.0 and $9.8 \%$ with $\mathrm{F} 1 \mathrm{PPq} 1 \mathrm{C} 1, \mathrm{~F} 1 \mathrm{PPq} 1 \mathrm{C} 2$ and $\mathrm{F} 1 \mathrm{PPq} 2 \mathrm{C} 2$ treatments, respectively.
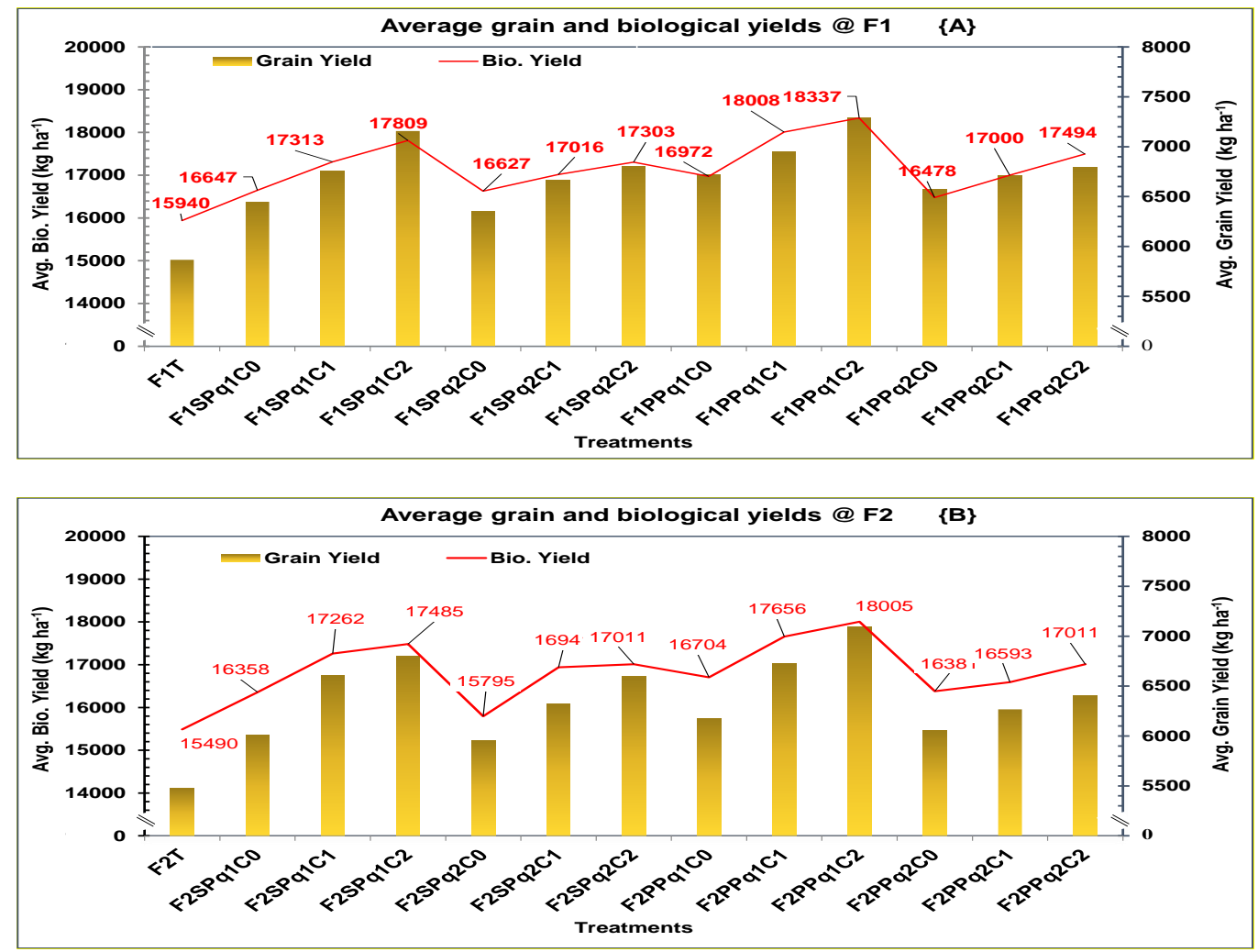

Fig. (7): Average values of grain and biological yields at F1 (A) and F 2 (B).

On the other field, Fig. (7-B) shows the average values of grain and biological yield at F2, regarding the effect of irrigation method, flow rate and compost rates, it was clear that the control treatment $\mathrm{F} 2 \mathrm{~T}$ recorded $5477 \mathrm{~kg} \mathrm{ha}^{-1}$ with significant increases with SP treatments of F2SPq1C1, F2SPq1C2, F2SPq2C1 and F2SPq2C2, which inducing significant increment percentage values were 20.7, 24.2, 15.4 and $20.4 \%$, respectively. While the increment percentage values through applied PP treatments compared with F2T reached 22.9, 29.6, 14.4 and $17.0 \%$ with $\mathrm{F} 2 \mathrm{PPq} 1 \mathrm{C} 1, \mathrm{~F} 2 \mathrm{PPq} 1 \mathrm{C} 2, \mathrm{~F} 2 \mathrm{PPq} 2 \mathrm{C} 1$ and $\mathrm{F} 2 \mathrm{PPq} 2 \mathrm{C} 2$ treatments, respectively.

The average biological yield in F2T treatment was $15490 \mathrm{~kg} \mathrm{ha}^{-1}$, it was a significant difference compared to F2SPq1C1 and F2SPq1C2 treatments, with increasing values reached 11.4 and $12.9 \%$, respectively. While the increment percentage values through applied PP treatments compared with F2T treatment reached 14.0 and $16.2 \%$ with F2PPq1C1 and F1PPq1C2 treatments, respectively. 
These results may be attributed to the improved root growth in the topsoil layer under IMP might sense to the soil drying more strongly than the lower subsoil to improve the allocation rate of carbohydrate to grains and then result in improved grain yield, Liu et al., (2015). The on-farm irrigation efficiency improvement and the conveyance losses decrease will result from a very important decrease in irrigation runoff and deep percolation losses. As a consequence, deep percolation will be reduced, then the mass of exported fertilizers and other salts will be decreased, then leads to better control of fertilizer application and reduces fertilizer use, Lecina et al., (2009).

\section{-Amounts of irrigation water used and water saving:}

The average values of irrigation water applied and water use efficiency of farm F1 showed in Fig. (8-A), the effect of IMP was obviously with rationalizing irrigation water compared with the TMP which F1T treatment used an average of $7635 \mathrm{~m}^{3} \mathrm{ha}^{-1}$ during the cultivated season, while, applied IMP treatments, the conservation percentage of water by q1 treatments ranged from 12.0 to13.6 \% compared with TMP and depending on applied compost rates with nonsignificant differences between irrigation distribution methods in IMP. While using q2, it was clear that the conservation percentage reached about 5.0 to $6.5 \%$ compared with TMP. And depending on applied compost rates, there were non-significant differences between the irrigation distribution treatments in IMP.

On the other farm, Fig. (8-B) shows the average values of irrigation water applied and water use efficiency at F2. The effect of IMP was obviously with rationalizing irrigation water compared with the TMP. Where, F2T treatment used an average of $6952 \mathrm{~m}^{3} \mathrm{ha}^{-1}$ during the cultivated season and by applying IMP treatments the conservation percentage of water by q1 treatments ranged from 10.0 to $11.5 \%$ compared with TMP. And depending on applied compost rates there were non-significant differences between irrigation distribution methods in IMP. While using q2, it was clear that the conservation percentage reached about $3.5-4.5 \%$ compared with TMP and were non-significant differences between irrigation distribution treatments.

The results of water rationalizing obtained by applying IMP (WinSRFR recommendations) treatments were attributed to a good management practice under conditions of each farm.

\section{- Irrigation water use efficiency (IWUE):}

Concerning, irrigation water use efficiency of grain yield (IWUEg.) at F1, Fig. (8-A) F1T treatment recorded an average value of $0.77 \mathrm{~kg} . \mathrm{m}^{-3}$. While, by comparing with applied IMP and SP treatments, the increment percentages by q1 ranged from 25.0 to $41.0 \%$, but using q2, it reached from 15.0 to $24.1 \%$, depending on applied compost rates. On the other hand, by applied IMP and PP treatments, the increment percentages by q1 treatments ranged from 30.8 to 43.8 $\%$, but using q2, it decreased from 18.0 to $23.5 \%$, depending on applied compost rates.

Concerning irrigation water use efficiency of biological yield (IWUE ${ }_{\text {bio }}$ ), Fig. (8-A) showed that IWUE bio was obviously that F1T treatment records an average value of $2.1 \mathrm{~kg} . \mathrm{m}^{-3}$, while applied IMP and SP treatments, the increment percentages by q1 ranged from 18.7 to $29.1 \%$, but using q2, it ranged from 10.9 to $16.1 \%$ depending on applied compost rates. Also, regarding

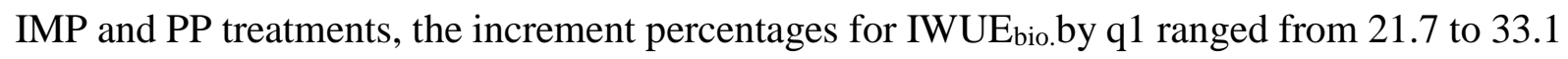
$\%$, but using q2, it ranged from8.9 to17.0 \% compared with TMP depending on applied compost rates. 

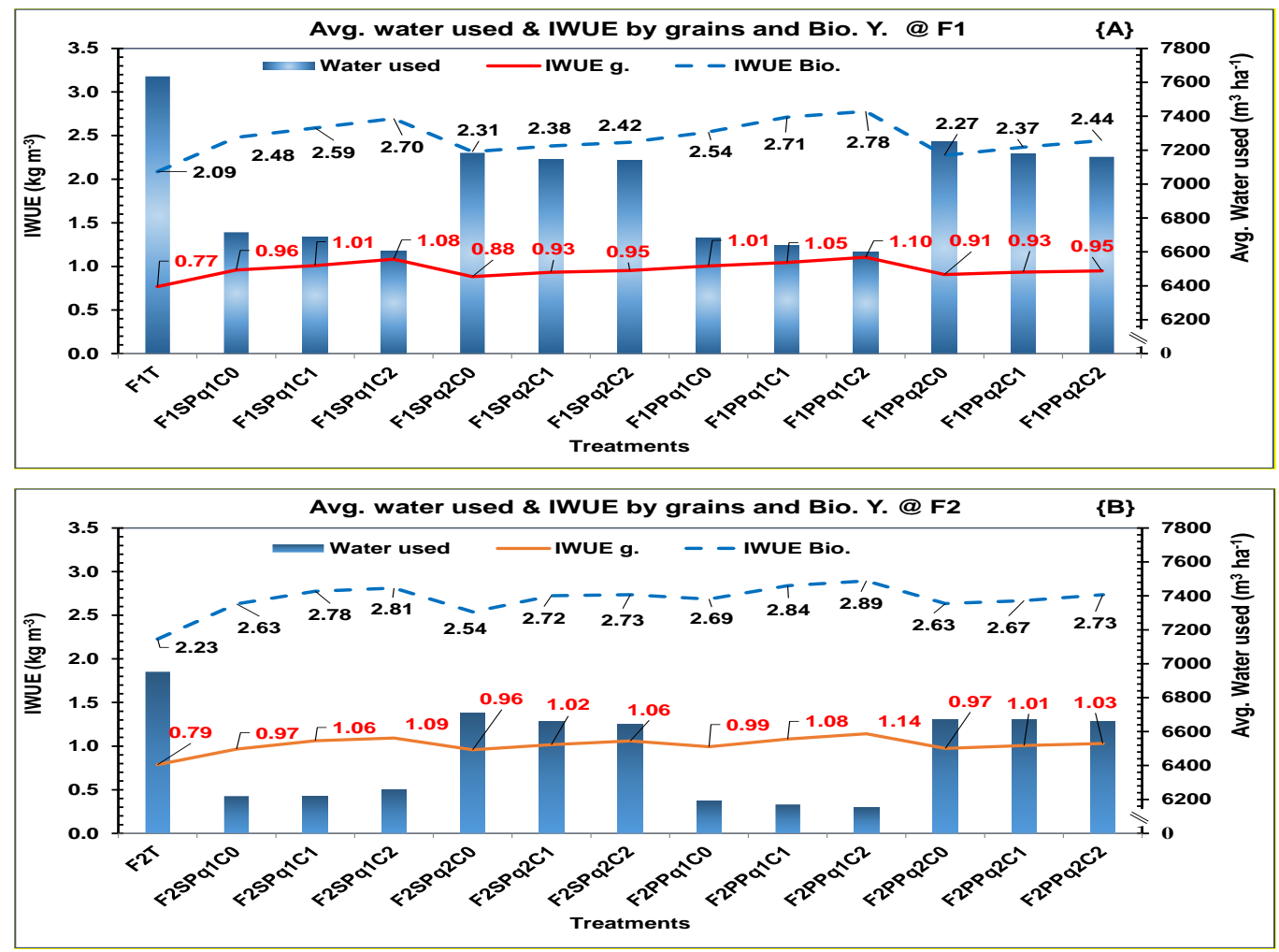

Fig. (8): Average irrigation water used $\left(\mathrm{m}^{3} \mathrm{ha}^{-1}\right)$ and irrigation water use efficiency (IWUE) for grain and biological yields $\left(\mathrm{kg} \mathrm{m}^{-3}\right)$ at $\mathrm{F} 1\{\mathbf{A}\}$ and $\mathrm{F} 2\{\mathbf{B}\}$.

On the other side, results of IWUE for both grain and biological yields in the second farm (F2) Fig. (8-B) showed that the IWUEg of F2T treatment recorded an average value of $0.79 \mathrm{~kg} \mathrm{~m}^{-3}$, while by applied IMP and SP treatments, the increment percentages by q1 ranged from 22.7 to $38.8 \%$ while using $\mathrm{q} 2$, it ranged from 21.6 to $34.5 \%$, depending on applied compost rates. On the other hand, by comparing applied IMP and PP treatments with TMP, the increment percentages of IWUEg. by q1 treatments ranged from 26.1 to $44.8 \%$, while using q2, it ranged from 23.6 to $30.8 \%$, depending on applied compost rates.

Concerning irrigation water use efficiency the obtained result of biological yield (IWUE $\mathrm{bio}_{\text {. }}$ ), Fig. (8-B) showed that IWUE bio. $_{\text {. }}$ F2T treatment recorded an average value of $2.23 \mathrm{~kg} \mathrm{~m}^{-3}$, while applied IMP and SP treatments the increment percentages ranged from 18.0 to $26.2 \%$, while by using q2, it ranged from 14.0 to $22.8 \%$ compared with TMP treatment, depending on applied compost rates. Also regarding IMP and PP treatments, the increment percentages of IWUE $_{\text {bio. }}$ by q1 ranged from 20.5 to $29.9 \%$, while using q2, it ranged from 18.2 to $22.7 \%$ compared with TMP treatment depending on applied compost rates.

Generally, the IWUE for both grain and biological yields by the treatments cultivated with IMP was greater than that in TMI. Consequently, The IWUE for the farms treated by IMP was higher than that in TMP. Based on the results of the two farms, this indicates that applying improvements management in soil and irrigation practices for cultivation of wheat crop under experimental conditions leads to an increase in the average IWUE by more than doubled compared with the traditional management practices. The resulted data clearly showed that better irrigation scheduling through IMP gave the best impact on enhanced properties of the wheat crop yield, under the conditions of the experiment area. And this result agrees with 
Carmier et al., (2006) and Hussein and Alva (2014) whose reported that adequate availability of water and nutrients is important to support optimal plant growth and production in the arid and semi-arid regions. And also agree with Raza et al., (2012) whose stated that the main prime factor of crop, soil and irrigation management is an increase in the proportion of plant water uptake (transpiration) in relation to runoff, soil evaporation and drainage. Thereby the most management contributes to better water use efficiency by improving water availability to the crop while reducing unproductive water losses. Thus, using the proper amount of irrigation water based on plant requirements and its site specific method application can ensure reasonable gains in water use efficiency. In the end, the result agrees with Shahani et al., (2016) whose concluded that the adoption of laser leveling technology helps in reducing the farm input costs, improve water use efficiency and enhance crop productivity.

\section{SUMMARY AND CONCLUSION}

Using of improved management practices IMP under conditions of the studied farms with long narrow borders resulted in enhanced water distribution uniformity, saved irrigation water and maximized the irrigation water use efficiency compared with traditional management practices TMP. Meanwhile, using WinSRFR simulation outputs gave a benefit where its impact was very pronounced in the applied and distribution irrigation water and management, consequently, good productivity of wheat.

Application of IMP with compost rate C2 under SP or PP water distribution interaction treatments recorded the first order based on the results of the growing season, while, with compost rate $\mathrm{C} 1$ under SP or PP interaction treatments recorded the second order.

On the other hand, and according to the regional conditions and benefit from the application of improved land and water management procedures, the farmers can use the saved amounts of irrigation water to add new areas and this is considered the benefit of agricultural sustainability and horizontal expansion increasing.

\section{ACKNOWLEDGMENT}

This work has been done under the help of the DRC research team of DRC Research Program: "Management of Groundwater and Development Irrigation in New Valley - Farafra Oasis".

\section{REFERENCES}

Abdelmageed, K., CHANG, X. H., WANG, D. M., WANG, Y. J., YANG, Y. S., ZHAO, G. C., \& TAO, Z. Q. (2019). Evolution of varieties and development of production technology in Egypt wheat: A review. Journal of Integrative Agriculture, 18(3), 483-495.

ASCE(1978)." Describing irrigation efficiency and uniformity". J. lrrig. and Drain. Engrg. ASCE, 104 (1): 35 - 41.

Bautista, E., A.J. Clemmens, T.S. Strelkoff, and M. Niblack (2009). Analysis of surface irrigation systems with WinSRFR_Example application Agric. Water Manag. 96: 11621169.

Bautista, E., J.L. Schlegel, and, T.S.Strelkoff (2012).WinSRFR 4.1.3 - User Manual. USDA-ARS Arid Land Agricultural Research Center. 21881 N. Cardon Lane, Maricopa, AZ, USA.

Black, C. A. “Ed.”(1983). Methods of soil analysis. Part 2, Agron.Monogr.No.9, ASA, Madison, WI, USA. 
Carmier, A.; Y. Aharoni; M. Edelstein; N. Umiel; A. Hagiladi; E. Yousef; M. Nikbachat; A. Zenou and J. Miron (2006). Effects of irrigation and plant density on yield, composition and in vitro digestibility of a new forage sorghum variety, TAL, at two-maturity stage. Animal Feed Science and Technology, 131: 121 - 133.

Clemmens, A. J.; Z. El-Haddad and T. S. Strelkoff (1999).Assessing the potential for modern surface irrigation in Egypt. Trans. of the ASAE 42 (4): 995-1008.

Dorrenbos, J. and W. O. Pruitt (1977).Crop Water Requirements. FAO Irrigation and Drainage Paper 24, 156 pp. Rome, Italy.

FAO (2010). (Food and Agriculture Organization of the United Nations). Valuing Rangelands for the Ecosystem and Livelihood Services. Proc., $30^{\text {th }}$ FAO Regional Conference for the Near East, Khartoum, the Republic of Sudan.

FAO (2013).FAOSTAT, World Crop production data. Accessed on 23 March 2014. Available at, www.faostat.fao.org/site.

Fredriksen, B. (1983). On the collection of education statistics in developing countries: Purpose, principles, procedures and problems. International Journal of Educational Development, 3(3), 291-304.

Gillies, M. H. (2008). Managing the effect of infiltration variability on the performance of surface irrigation. Ph.D. Thesis, University of Southern Queensland, Toowoomba. http://eprints.usq.edu.au/id/eprint/4082

Hamza, M.A., and W.K. Anderson (2005). Soil compaction in cropping systems. A review of the nature, causes and possible solutions. Review Article, Soil \& Tillage Res. J. 82: 121145

Hiekal, H. A. M. (2007). Efficiency of surge furrow irrigation system on soil water distribution uniformity under calcareous soils irrigated by saline water. Arab Conf. of Soil and Water Mgt. for Sust. Agric. Devlop., 10 - 11 Apr. 2007, Fac. of Agric., Mansoura U.: 97 - 107.

Hodgkinsona, L, I.C. Dodda, A. Binleya, R.W. Ashtonb, R.P. Whiteb, C.W. Wattsb, and W.R. Whalleyb (2017). Root growth in field-grown winter wheat: Some effects of soil conditions, season and genotype. Eur. J. Agron. 91: 74-83.

Hussein, M. M. and A. K. Alva (2014). Growth, yield and water use efficiency of forage sorghum as affected by NPK fertilizer and deficit irrigation. American Journal of Plant Sciences, 5: 2134 - 2140.

Ismail, S. M. (2002). "Design and Management of Field Irrigation Systems", Pp: 5-188, Elmarefa, Alex. (In Arabic)

James, L. G. (1988). Principles of Farm Irrigation System Design. Jone Willey \& Sons (Ed.), New York, $543 \mathrm{pp}$.

Kanber, R., H. Köksal , S. Önder , S. Kapur and S. Sahan (2001). Comparison of surge and continuous furrow methods for cotton in the Harran plain. Agric. water manag., 47(2), 119-135. 
Klute, A. "Ed.”(1986). Water Retention: Laboratory Methods. Chapter 26: Hbook of Methods of Soil Analysis. Part 1.Second Ed. Am. Soc. Agron. Soil Sci. Soc. Am., Madison, WI., USA.

Lecina, S., D. Isidoro, E.Playán, R. Araguiés (2009). Effect of irrigation modernization on the quantity and quality of water: the Ebro basin as a case study. Monographs INIA. Agricultural series.No. 26. INIA, Madrid, p 92.

Liu, X., X. Zhang, S. Chen, H. Sun, and L.Shao (2015). Subsoil compaction and irrigation regimes affect the root-shoot relation and grain yield of winter wheat. Agric. Water Manag. 154: $59-67$.

Merriam, J. L.; M. N. Shearer and C. M. Burt (1983). Evaluating irrigation systems and practices. Chapter 17 In Jensen, M. E. (Ed.): Design and operation of farm irrigation systems. ASAE Monograph No. 3, USA.

Morozov, V.; V. Ushkarenko and P. Laze (2010). Integrate Water Resources Management on the Irrigated Lands of the South of Ukraine in the Global Climate Changes Conditions. BALWOIS 2010 - Ohrid, Republic of Macedonia - 25, 29 May, Pp: 3.

Pereira, L. S. (1999). Higher performances through combined improvements in irrigation methods and scheduling: a discussion. Agric. Water Manage. 40, 153-169

Raza, A.; J. K. Friedel and G. Bodner (2012).Improving Water Use Efficiency for Sustainable Agriculture. In Sustainable Agriculture Reviews Vol. (8), Eric Lichtfouse (Edt.), Agroecology and Strategies for Climate Change, Library of Congress Control No. 2011935458. Pages: 167 - 211.

Shahani, W. A.; F. Kaiwen and A. Memon (2016).Impact of Laser leveling technology on water use efficiency and crop productivity in the cotton - wheat cropping system in Sindh. Intern. J. of Res. - Granthaalayah, Vol. 4, (2): 220-231.

Sharkawy, S. F. T., H. S.Khafaga, H. A. M. Hiekal and A. A. Mousa (2017). Increasing salt tolerance of Egyptian clover by using integrated management system under marginal conditions in El-Tina Plain- North Sinai - Egypt. Egypt. J. Appl. Sci., 32(9): 335 - 378.

Snedecor, G. W. and Cochran, W. G. (1990).Statistical Methods. $8^{\text {th }}$ Edition, Iowa State University, Iowa. 


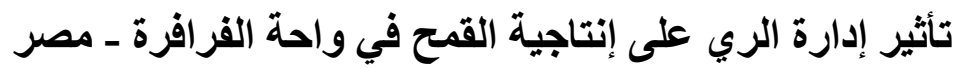

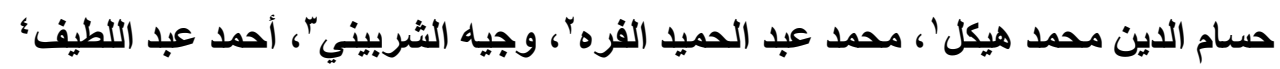

$$
\begin{aligned}
& \text { ' أستاذ مساعد - قسم صيانة الأر اضي و المياه - مركز بحوث الصحر اء - القاهرة - مصر. } \\
& \text { r باحث ـ قنم صيانة الأر اضي و المياه ـ مركز بحوث الصحر اء ـ القاهرة - مصر. }
\end{aligned}
$$

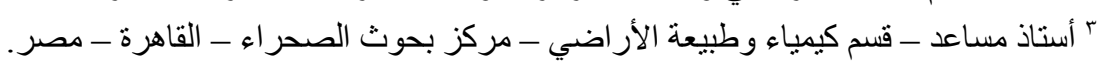

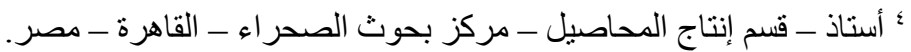

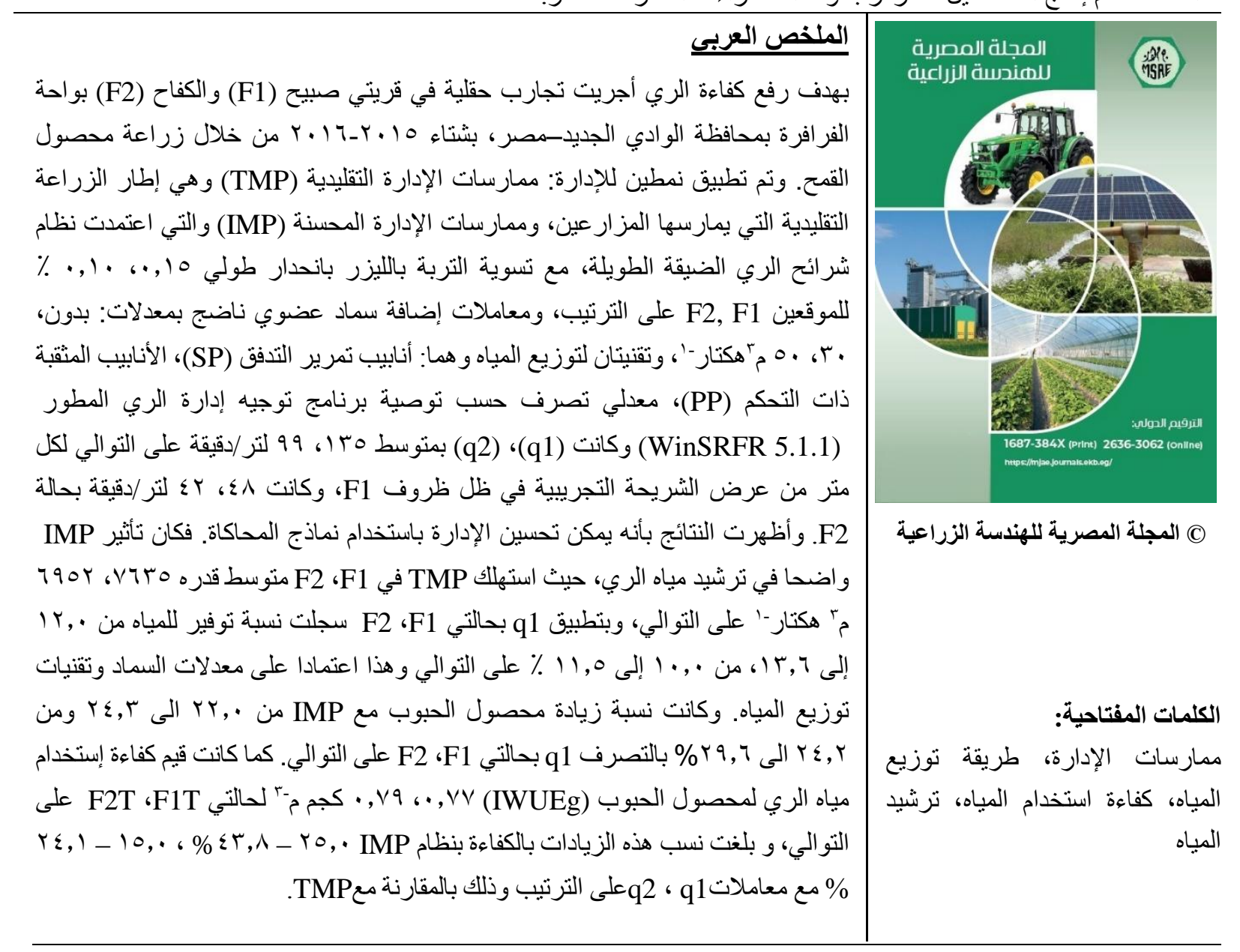

